\title{
The treatment of optimizing container transportation dynamic programming and planning
}

\author{
Elena Korchagina ${ }^{\text {l, }}$, Andrey Bochkarev ${ }^{2}$, Pavel Bochkarev ${ }^{2}$, Sergey Barykin ${ }^{1}$ and Svetlana \\ Suvorova ${ }^{1}$ \\ ${ }^{1}$ Peter the Great St. Petersburg Polytechnic University, Polytechnicheskaya, 29, St. Petersburg, \\ 195251, Russia \\ ${ }^{2}$ National Research University Higher school of Economics, Saint-Petersburg branch, Str. \\ Kantemirovskaya, 3A, St. Petersburg, 194100, Russia
}

\begin{abstract}
The article addresses the treatment of applying the method of dynamic linear programming to solve the task of choosing the optimal strategy for the containers dispatch, taking into account the significant unevenness of loading and shipment of containers. The optimizing container transportation dynamic planning could be treated as mathematical model of the dynamic multi-period task of the loaded containers shipment, which allows the choice of the optimal strategy for sending containers, taking into account the significant unevenness of their loading and dispatch from the railway freight station. The efficiency of considered method is proved by numerical calculation being presented to disclose the dynamic linear programming algorithm implementing to solve the problem.
\end{abstract}

\section{Introduction}

The scientific task covers the development of conceptual approach for the optimizing container transportation dynamic planning which could be treated as dynamic multi-period task of the loaded containers shipment. Being treated as mathematical model of the optimizing container transportation the suggested economical model allows the choice of the optimal strategy for sending containers. One should take into account the significant unevenness of their loading and dispatch from the railway freight station.

The models of dynamic and stochastic programming have become widely used in planning operations over the past thirty years in management of supply chains [1]. The analysis of the famous works [2-7] shows that decision trees and the planning of scenarios based on their analysis are the main tools in the management of uncertainty and risk in math programming models. It should be noted that optimization models and, in particular, dynamic and stochastic programming models [8-12] are used for solving tasks of optimization of logistic network, reserves management and transportation routing. Some

* Corresponding author: $\underline{\text { sbe } @ \text { list.ru }}$ 
authors examine the theoretical aspects of logistics and optimizing transportation models [13-15]. However, the use of these models in logistics is still insufficient.

The first part of the article contained informative and math statement of dynamic multiperiod task of shipment of loaded containers which allows taking into consideration possible changes in supply amounts over planning periods as well as possible unevenness of cargo shipment (its delay) from railroad goods depot. Let's consider the numerical example of task solving.

\section{Materials and Methods}

The researching method involves the complex of a dynamic programming procedures for solving the problems of container transportation of goods. Container cargos could be shipped to the consumers according to the following scheme:

- loaded containers are transported to the container site of the railway freight station;

- containers are put on a temporary storage warehouse (TSW);

- containers are idle on the TSW till the customs clearance is finished in the export regime and until loaded on the railway platform, idle period is 3 days on average;

- then the containers are shipped by railway to the destination (port).

Let Us assume the following optimizing container transportation task. There are three alternative options for loading or stuffing containers:

1) on the floor with its subsequent loading on the vehicle by means of a crane;

2) on the floor with its subsequent loading on the vehicle by means of jacks;

3) without removing the container from the vehicle.

The advantage of loading containers on the floor is that this scheme of loading reduces the cost of storage of the loaded containers on the TSW in anticipation of the formation of wagons. Disadvantages: the use of lifting equipment is limited by the space of the warehouse (low ceiling and lack of space for stacking of loaded containers); capital investments are required for purchasing of lifting equipment. The cost of road transport depends on several factors. First, on the type of containers that are used. There are two options: the use of 20 foot containers with a capacity of 21.5 tons or 40 foot containers with a capacity of 27.5 tons. Secondly, on transport that is used for the shipment, weather it is owned or rented. Thus, it is required to organize the delivery of the loaded containers to the container site of the railway freight station with minimal costs. Three ways of loading of two types of the containers and two options of the use of vehicles lead to 12 options for containers shipment from the plant to the container site of the railway freight station, which differ in terms of costs:

1. Dispatch of cargos in 20-foot containers:

Own transport with loading:

- on the floor using a crane or jacks;

- into the vehicle;

Third-party vehicles with loading:

- on the floor using a crane or jacks;

- into the vehicle.

2. Dispatch of goods in 40 - foot containers:

Own transport with loading:

- on the floor using a crane or jacks;

- into the vehicle.

Third-party vehicles with loading:

- on the floor using a crane or jacks;

- into the vehicle. 
Ошибка! Источник ссылки не найден. presents the calculation of the cost of a loaded container shipment.

Table 1. Calculation of costs for shipment of loaded containers

\begin{tabular}{|c|c|c|c|c|c|c|c|c|c|c|c|c|c|}
\hline \multirow{5}{*}{ Indicators } & \multirow{5}{*}{$\begin{array}{c}\text { Meas. } \\
\text { units }\end{array}$} & \multicolumn{6}{|c|}{20 feet container } & \multicolumn{6}{|c|}{40 feet container } \\
\hline & & \multirow{2}{*}{\multicolumn{3}{|c|}{$\frac{\text { own transport }}{\text { loading }}$}} & \multirow{2}{*}{\multicolumn{3}{|c|}{\begin{tabular}{|c|} 
third-party vehicles \\
loading \\
\end{tabular}}} & \multirow{2}{*}{\multicolumn{3}{|c|}{$\begin{array}{c}\text { own transport } \\
\text { loading } \\
\end{array}$}} & \multirow{2}{*}{\multicolumn{3}{|c|}{\begin{tabular}{|c|} 
third-party vehicles \\
loading
\end{tabular}}} \\
\hline & & & & & & & & & & & & & \\
\hline & & \multicolumn{2}{|c|}{$\begin{array}{c}\text { on the floor } \\
\text { using }\end{array}$} & \multirow{2}{*}{$\begin{array}{l}\text { into the } \\
\text { vehilce }\end{array}$} & \multicolumn{2}{|c|}{$\begin{array}{c}\text { on the floor } \\
\text { using }\end{array}$} & \multirow{2}{*}{$\begin{array}{l}\text { into the } \\
\text { vehilce }\end{array}$} & \multicolumn{2}{|c|}{ on the floor using } & \multirow{2}{*}{$\begin{array}{l}\text { into the } \\
\text { vehilce }\end{array}$} & \multicolumn{2}{|c|}{ on the floor using } & \multirow{2}{*}{$\begin{array}{c}\text { into } \\
\text { the } \\
\text { vehilc } \\
\text { e }\end{array}$} \\
\hline & & crane & jacks & & crane & jacks & & crane & jacks & & crane & jacks & \\
\hline 1 Average route time & hour & 1.33 & 1.33 & 1.33 & 2.33 & 2.33 & 2.33 & 1.33 & 1.33 & 1.33 & 2.33 & 2.33 & 2.33 \\
\hline $\begin{array}{l}\text { 2. The cost of } 1 \\
\text { vehicle. - hour }\end{array}$ & Rub. & 188.5 & 188.5 & 188.5 & 329.0 & 329.0 & 329.0 & 188.5 & 188.5 & 188.5 & 329.0 & 329.0 & 329.0 \\
\hline $\begin{array}{l}\text { 3. The amount of costs } \\
\text { of road transport }\end{array}$ & Rub. & 250.7 & 250.7 & 250.7 & 766.5 & 766.5 & 766.5 & 250.7 & 250.7 & 250.7 & 766.5 & 766.5 & 766.5 \\
\hline $\begin{array}{l}\text { 4. The length of the } \\
\text { route }\end{array}$ & $\mathrm{km}$ & 16.0 & 16.0 & 16.0 & 16.0 & 16.0 & 16.0 & 16.0 & 16.0 & 16.0 & 16.0 & 16.0 & 16.0 \\
\hline $\begin{array}{l}\text { 5. The cost of cargo } \\
\text { freight station }\end{array}$ & Rub. & 5811.7 & 5811.7 & 6805.7 & 5811.7 & 5811.7 & 6805.7 & 6674.6 & 6674.6 & 7668.6 & 6674.6 & 6674.6 & 7668.6 \\
\hline $\begin{array}{l}\text { 5.1. Storage of empty } \\
\text { containers }\end{array}$ & Rub. & 4176.0 & $4176 ., 0$ & 4176.0 & 4176.0 & 4176.0 & 4176.0 & 4176.0 & 4176.0 & 4176.0 & 4176.0 & 4176.0 & 4176.0 \\
\hline $\begin{array}{l}5.2 . \text { Storage of loaded } \\
\text { containers }\end{array}$ & Rub. & 496.0 & 496.0 & 1490.0 & 496.0 & 496.0 & 1490.0 & 496.0 & 496.0 & 1490.0 & 496.0 & 496.0 & 1490.0 \\
\hline $\begin{array}{l}\text { 5.3. Fee for untimely } \\
\text { cargo provision before } \\
\text { the appointed time of } \\
\text { loading }\end{array}$ & Rub. & 628.7 & 628.7 & 628.7 & 628.7 & 628.7 & 628.7 & 911.6 & 911.6 & 911.6 & 911.6 & 911.6 & 911.6 \\
\hline $\begin{array}{l}\text { 5.4. Loading and. } \\
\text { unloading operations }\end{array}$ & Rub. & 511.0 & 511.0 & 511.0 & 511.0 & 511.0 & 511.0 & 1091.0 & 1091.0 & 1091.0 & 1091.0 & 1091.0 & 1091.0 \\
\hline 6. Depreciation charges & Rub. & 531.0 & 208.77 & & 531.0 & 208.8 & & 1216.2 & 804.0 & 536.9 & 679.2 & 267.0 & \\
\hline 6.1. Lifting equipment & Rub. & 531.0 & 208.77 & & 531.0 & 208.8 & & 679.2 & 267.0 & & 679.2 & 267.0 & \\
\hline $\begin{array}{l}\text { 6.2. Road transport } \\
\text { equipment }\end{array}$ & Rub. & & & & & & & 536.9 & 536.9 & 536.9 & & & \\
\hline 7. Total costs & Rub. & 6593.4 & 6271.1 & 7056.4 & 7109.2 & 6786.9 & 7572.2 & 8141.4 & 7729.2 & 8456.2 & 8120.3 & 7708.1 & 8435.1 \\
\hline $\begin{array}{l}\text { 8. Weight of cargo } \\
\text { (gross) in the container }\end{array}$ & $\mathrm{t}$ & 21.5 & 21.5 & 21.5 & 21.5 & 21.5 & 21.5 & 27.5 & 27.5 & 27.5 & 27.5 & 27.5 & 27.5 \\
\hline $\begin{array}{l}\text { 9. Costs per ton of } \\
\text { cargo }\end{array}$ & Rub. & 306.7 & 291.7 & 328.2 & 330.7 & 315.7 & 352.2 & 296.1 & 281.1 & 307.5 & 295.3 & 280.3 & 306.7 \\
\hline
\end{tabular}

Analysis of the data presented in Ошибка! Источник ссылки не найден., shows, first, that the cost of shipment of loaded containers (line 7) is composed by three components: the costs for road transport (line 3), the cost of freight commodity station (line 5) and depreciation charges for lifting equipment and vehicles (line 6). Secondly, the shipment of goods by 40 - foot containers is cheaper than by 20 -foot containers calculated per 1 ton of cargo (line 9). Third, the cost of shipment of loaded containers by owned vehicles is lower only for 20 -foot containers. Transportation of 40 -foot containers by own vehicles will be more expensive, because for this purpose new purchased semi-trailerscontainer carriers are used, and, accordingly, depreciation is accrued. It should be noted here that for the own vehicles intended for transportation of 20-foot containers, depreciation is not charged due to its full wear and tear. Analyzing the data presented in Ошибка! Источник ссылки не найден., it can also be concluded that the most profitable way to send 20-foot containers is to send own vehicles- with stuffing on the floor and further loading using jacks, and 40-foot containers - shipment by third-party vehicles with stuffing on the floor and loading using jacks (the costs corresponding to these options for containers shipment are highlighted in the Ошибка! Источник ссылки не найден.).

Thus, if additional restrictions apply to the shipment of the containers, the least costly options should be used. In the problem under consideration, additional restrictions can be imposed on the number of containers that are loaded on the floor and, accordingly, must be loaded on vehicles using a crane or jacks, as well as on the number of goods that must be sent by 20 and 40 foot containers. In addition, in this task it is necessary to take into account the uneven dispatch of products from the railway freight station and to minimize 
the costs associated with untimely cargo provision before the appointed time of loading. Since human logic often comes to a standstill when solving complex problems, when the required variables are subject to a large number of restrictions, it is advisable to build a mathematical model of the problem and get the optimal solution.

\section{Results}

Let's assume that the volume of the delivery of container cargoes $Q_{0}$ is 1500 tons per month. Loading of containers at the plant is performed unevenly: $Q^{*}{ }_{1}=600$ ton in the first week of each month, $Q_{2}^{*}=400$ ton in the second week, $Q_{3}^{*}=300$ ton in the third week while in the fourth week $Q^{*}{ }_{4}=200$ ton. The shipment of containers from goods depot should be performed evenly, $Q_{t}=375$ ton, $t=\{1,2,3,4\}$. Moreover, the amount of shipped goods packed in twenty-foot containers should be no less than: 300 ton during the first week $\left(Q_{1,1}=300\right.$ ton), 200 ton during the second week $\left(Q_{1,2}=200\right.$ ton), 150 ton during the third week $\left(Q_{1,3}=150\right.$ ton) and 100 ton during the fourth week $\left(Q_{1,4}=100\right.$ ton). If fact, this requirement is often violated due to delay of shipment from the depot for a duration of seven days or one week. Let's consider the following scenarios.

1) Scenario 1 (basic): we assume that there have been no breakouts in the shipment of containers from goods deport in the whole planning period $t \in\{1, \ldots, T\}$.

2) Scenario 2, in which $y_{i, j, t}=0, \forall i, j, t=1$ and, respectively, $Q_{i, t}=0, \forall i, t=1$ - i.e. trains with container cargoes have not been dispatched from goods depot during the $1^{\text {st }}$ week. Let's assume that the delay of dispatch of the train with container goods is 7 days long, and cargoes should be therefore shipped within $2^{\text {nd }}$ week.

3) Scenario 3, in which $y_{i, j, t}=0, \forall i, j, t=2$ and, respectively, $Q_{i, t}=0, \forall i, t=2$ - i.e. trains with container cargoes have not been dispatched from goods depot during the $2^{\text {st }}$ week. Let's assume that the delay of dispatch of the train with container goods is 7 days long, and cargoes should be therefore shipped within $3^{\text {rd }}$ week.

4) Scenario 4, in which $y_{i, j, t}=0, \forall i, j, t=3$ and, respectively, $Q_{i, t}=0, \forall i, t=3$ - i.e. trains with container cargoes have not been dispatched from goods depot during the $3^{\text {rd }}$ week. Let's assume that the delay of dispatch of the train with container goods is 7 days long, and cargoes should be therefore shipped within $4^{\text {th }}$ week.

The shipment of container cargoes is a subject of extra limitations. The number of containers ready for weekly shipment with ground container packing and its further loading onto container chassis by means of the crane or jacks is 5 pcs for any proposed loading approach. Plant warehouse is capable to hold no more than 20 twenty-feet containers and no more than 10 forty-feet ones. To find the solution one should calculate optimal percentage of loaded containers $x_{i, j, t}$, the percentage of shipped ones $y_{i, j, t}$ and the percentage of those transferred for storage $d_{i, j, t}$ at which common delivery costs would reach their minimum. The numerical result of proposed task is possible to obtain through Excel add-on, as this work implies processing of large-size data package. The search of solutions is performed with Analytic Solver Platform add-on. Solution results for this task upon Scenario 1(basic) are represented in Ошибка! Источник ссылки не найден. 
Table 2. The result of solution of the task of shipment of packed containers (Scenario 1)

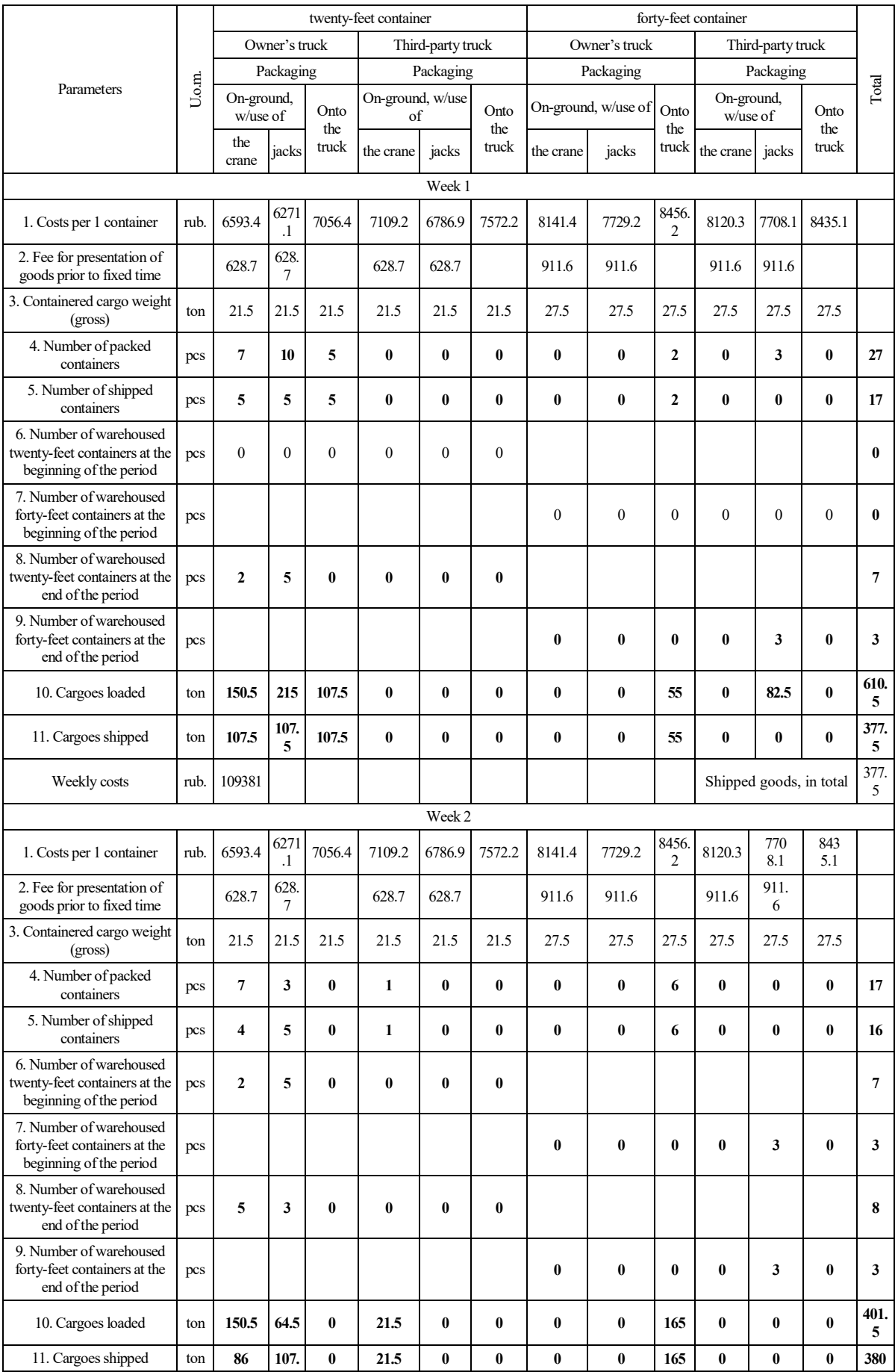




\begin{tabular}{|c|c|c|c|c|c|c|c|c|c|c|c|c|c|c|}
\hline & & & 5 & & & & & & & & & & & \\
\hline Weekly costs & rub. & 107811 & & & & & & & & & \multicolumn{3}{|c|}{ Shipped goods, in total } & 380 \\
\hline \multicolumn{15}{|c|}{ Week 3} \\
\hline 1. Costs per 1 container & rub. & 6593.4 & $\begin{array}{c}6271 \\
.1\end{array}$ & 7056.4 & 7109.2 & 6786.9 & 7572.2 & 8141.4 & 7729.2 & $\begin{array}{c}8456 \\
2\end{array}$ & 8120.3 & $\begin{array}{l}770 \\
8.1\end{array}$ & $\begin{array}{l}843 \\
5.1\end{array}$ & \\
\hline $\begin{array}{l}\text { 2. Fee for presentation of } \\
\text { goods prior to fixed time }\end{array}$ & & 628.7 & $\begin{array}{c}628 . \\
7 \\
\end{array}$ & & 628.7 & 628.7 & & 911.6 & 911.6 & & 911.6 & $\begin{array}{c}911 . \\
6\end{array}$ & & \\
\hline $\begin{array}{l}\text { 3. Containered cargo weight } \\
\text { (gross) }\end{array}$ & ton & 21.5 & 21.5 & 21.5 & 21.5 & 21.5 & 21.5 & 27.5 & 27.5 & 27.5 & 27.5 & 27.5 & 27.5 & \\
\hline $\begin{array}{l}\text { 4. Number of packed } \\
\text { containers }\end{array}$ & pes & 2 & 3 & $\mathbf{0}$ & $\mathbf{0}$ & $\mathbf{0}$ & $\mathbf{0}$ & $\mathbf{0}$ & 0 & $\mathbf{0}$ & $\mathbf{0}$ & 1 & 6 & 12 \\
\hline $\begin{array}{l}\text { 5. Number of shipped } \\
\text { containers }\end{array}$ & pes & 5 & 5 & $\mathbf{0}$ & $\mathbf{0}$ & $\mathbf{0}$ & $\mathbf{0}$ & $\mathbf{0}$ & $\mathbf{0}$ & $\mathbf{0}$ & $\mathbf{0}$ & $\mathbf{0}$ & 6 & 16 \\
\hline $\begin{array}{l}\text { 6. Number of warehoused } \\
\text { twenty-feet containers at the } \\
\text { beginning of the period }\end{array}$ & pes & 5 & 3 & $\mathbf{0}$ & $\mathbf{0}$ & $\mathbf{0}$ & $\mathbf{0}$ & & & & & & & 8 \\
\hline $\begin{array}{l}\text { 7. Number of warehoused } \\
\text { forty-feet containers at the } \\
\text { beginning of the period }\end{array}$ & pcs & & & & & & & $\mathbf{0}$ & $\mathbf{0}$ & $\mathbf{0}$ & $\mathbf{0}$ & 3 & $\mathbf{0}$ & 3 \\
\hline $\begin{array}{l}\text { 8. Number of warehoused } \\
\text { twenty-feet containers at the } \\
\text { end of the period }\end{array}$ & pcs & 2 & 1 & $\mathbf{0}$ & $\mathbf{0}$ & $\mathbf{0}$ & $\mathbf{0}$ & & & & & & & 3 \\
\hline $\begin{array}{l}\text { 9. Number of warehoused } \\
\text { forty-feet containers at the } \\
\text { end of the period }\end{array}$ & pes & & & & & & & $\mathbf{0}$ & $\mathbf{0}$ & $\mathbf{0}$ & $\mathbf{0}$ & 4 & $\mathbf{0}$ & 4 \\
\hline 10. Cargoes loaded & ton & 43 & 64.5 & $\mathbf{0}$ & $\mathbf{0}$ & $\mathbf{0}$ & $\mathbf{0}$ & $\mathbf{0}$ & $\mathbf{0}$ & $\mathbf{0}$ & $\mathbf{0}$ & 27.5 & 165 & 300 \\
\hline 11. Cargoes shipped & ton & 107.5 & $\begin{array}{c}107 . \\
5\end{array}$ & $\mathbf{0}$ & $\mathbf{0}$ & $\mathbf{0}$ & $\mathbf{0}$ & $\mathbf{0}$ & $\mathbf{0}$ & $\mathbf{0}$ & $\mathbf{0}$ & $\mathbf{0}$ & 165 & 380 \\
\hline Weekly costs & rub. & 109400 & & & & & & & & & \multicolumn{3}{|c|}{ Shipped goods, in total } & 380 \\
\hline \multicolumn{15}{|c|}{ Week 4} \\
\hline 1. Costs per 1 container & rub. & 6593.4 & \begin{tabular}{|c|}
627 \\
1.1 \\
\end{tabular} & 7056.4 & 7109.2 & 6786.9 & 7572.2 & 8141.4 & 7729.2 & $\begin{array}{c}8456 \\
.2 \\
\end{array}$ & 8120.3 & $\begin{array}{l}770 \\
8.1 \\
\end{array}$ & $\begin{array}{l}843 \\
5.1 \\
\end{array}$ & \\
\hline $\begin{array}{l}\text { 2. Fee for presentation of } \\
\text { goods prior to fixed time }\end{array}$ & & 628.7 & $\begin{array}{c}628 . \\
7\end{array}$ & & 628.7 & 628.7 & & 911.6 & 911.6 & & 911.6 & $\begin{array}{l}911 \\
.6\end{array}$ & & \\
\hline $\begin{array}{l}\text { 3. Containered cargo } \\
\text { weight (gross) }\end{array}$ & ton & 21.5 & 21.5 & 21.5 & 21.5 & 21.5 & 21.5 & 27.5 & 27.5 & 27.5 & 27.5 & $\begin{array}{c}27 . \\
5\end{array}$ & $\begin{array}{c}27 . \\
5\end{array}$ & \\
\hline $\begin{array}{l}\text { 4. Number of packed } \\
\text { containers }\end{array}$ & pes & 3 & $\mathbf{0}$ & $\mathbf{0}$ & $\mathbf{0}$ & $\mathbf{0}$ & $\mathbf{0}$ & $\mathbf{0}$ & $\mathbf{0}$ & $\mathbf{0}$ & $\mathbf{0}$ & $\mathbf{0}$ & 5 & 8 \\
\hline $\begin{array}{l}\text { 5. Number of shipped } \\
\text { containers }\end{array}$ & pes & 5 & 1 & $\mathbf{0}$ & $\mathbf{0}$ & $\mathbf{0}$ & $\mathbf{0}$ & $\mathbf{0}$ & $\mathbf{0}$ & $\mathbf{0}$ & $\mathbf{0}$ & 4 & 5 & 15 \\
\hline $\begin{array}{c}\text { 6. Number of warehoused } \\
\text { twenty-feet containers at } \\
\text { the beginning of the } \\
\text { period }\end{array}$ & pes & 2 & 1 & $\mathbf{0}$ & $\mathbf{0}$ & $\mathbf{0}$ & $\mathbf{0}$ & & & & & & & 3 \\
\hline $\begin{array}{l}\text { 7. Number of warehoused } \\
\text { forty-feet containers at the } \\
\text { beginning of the period }\end{array}$ & pcs & & & & & & & $\mathbf{0}$ & $\mathbf{0}$ & $\mathbf{0}$ & $\mathbf{0}$ & 4 & $\mathbf{0}$ & 4 \\
\hline $\begin{array}{l}\text { 8. Number of warehoused } \\
\text { twenty-feet containers at } \\
\text { the end of the period }\end{array}$ & pes & $\mathbf{0}$ & $\mathbf{0}$ & $\mathbf{0}$ & $\mathbf{0}$ & $\mathbf{0}$ & $\mathbf{0}$ & & & & & & & $\mathbf{0}$ \\
\hline $\begin{array}{l}\text { 9. Number of warehoused } \\
\text { forty-feet containers at the } \\
\text { end of the period }\end{array}$ & pcs & & & & & & & $\mathbf{0}$ & $\mathbf{0}$ & $\mathbf{0}$ & $\mathbf{0}$ & $\mathbf{0}$ & $\mathbf{0}$ & $\mathbf{0}$ \\
\hline 10. Cargoes loaded & ton & 64.5 & $\mathbf{0}$ & $\mathbf{0}$ & $\mathbf{0}$ & $\mathbf{0}$ & $\mathbf{0}$ & $\mathbf{0}$ & $\mathbf{0}$ & $\mathbf{0}$ & $\mathbf{0}$ & $\mathbf{0}$ & $\begin{array}{c}137 \\
.5\end{array}$ & 202 \\
\hline 11. Cargoes shipped & ton & 107.5 & 21.5 & $\mathbf{0}$ & $\mathbf{0}$ & $\mathbf{0}$ & $\mathbf{0}$ & $\mathbf{0}$ & 0 & $\mathbf{0}$ & $\mathbf{0}$ & 110 & $\begin{array}{c}137 \\
.5\end{array}$ & $\begin{array}{c}376 . \\
5\end{array}$ \\
\hline Weekly costs & rub. & 112245 & & & & & & & & & Shipped & goods & in total & $\begin{array}{c}376 . \\
5\end{array}$ \\
\hline \multicolumn{15}{|c|}{ In total, for 4 weeks } \\
\hline $\begin{array}{l}\text { 1. Packed containers, in } \\
\text { total }\end{array}$ & pes & 19 & 16 & 5 & 1 & $\mathbf{0}$ & $\mathbf{0}$ & 0 & 0 & 8 & 0 & 4 & 11 & 64 \\
\hline $\begin{array}{l}\text { 2. Shipped containers, in } \\
\text { total }\end{array}$ & pes & 19 & 16 & 5 & 1 & 0 & 0 & 0 & 0 & 8 & 0 & 4 & 11 & 64 \\
\hline $\begin{array}{l}\text { 3. Warehoused twenty- } \\
\text { feet containers, in total }\end{array}$ & pes & 5 & 5 & 0 & 0 & 0 & 0 & & & & & & & 10 \\
\hline $\begin{array}{l}\text { 4. Warehoused forty-feet } \\
\text { containers, in total }\end{array}$ & pcs & & & & & & & 0 & 0 & 0 & 0 & 4 & 0 & 4 \\
\hline 5. Loaded cargoes, in total & ton & 408.5 & 344 & 107.5 & 21.5 & 0 & 0 & 0 & 0 & 220 & 0 & 110 & 302 & 151 \\
\hline
\end{tabular}




\begin{tabular}{|c|c|c|c|c|c|c|c|c|c|c|c|c|c|c|}
\hline & & & & & & & & & & & & & .5 & $\mathbf{4}$ \\
\hline $\begin{array}{c}\text { 6. Shipped cargoes, in } \\
\text { total }\end{array}$ & ton & 408.5 & 344 & 107.5 & 21.5 & 0 & 0 & 0 & 0 & 220 & 0 & 110 & $\begin{array}{c}302 \\
.5\end{array}$ & $\begin{array}{c}\mathbf{1 5 1} \\
\mathbf{4}\end{array}$ \\
\hline $\begin{array}{c}\text { Total costs for 4-week } \\
\text { period }\end{array}$ & rub. & \multicolumn{10}{|c|}{4388398} \\
\hline
\end{tabular}

The analysis of solutions found upon all four scenarios is reviewed through the structure of container shipment represented in Ошибка! Источник ссылки не найден.

Table 3. The analysis of use of different types of containers

\begin{tabular}{|c|c|c|c|c|c|}
\hline \multirow{2}{*}{ Parameters } & \multirow{2}{*}{ U.o.m. } & \multicolumn{4}{|c|}{ Values for the scenario } \\
\hline & & Scenario 1 & Scenario 2 & Scenario 3 & Scenario 4 \\
\hline $\begin{array}{l}\text { Total number of containers shipped, } \\
\text { incl.: }\end{array}$ & pes & 64 & 64 & 64 & 64 \\
\hline $\begin{array}{l}\text { twenty-feet containers with on-ground } \\
\text { packing and crane loading }\end{array}$ & pes & 20 & 11 & 17 & 20 \\
\hline $\begin{array}{l}\text { forty-feet containers with on-ground } \\
\text { packing and crane loading }\end{array}$ & pcs & 0 & 4 & 1 & 0 \\
\hline $\begin{array}{l}\text { Total number of containers shipped } \\
\text { with on-ground packing and crane } \\
\text { loading }\end{array}$ & pcs & 20 & 15 & 18 & 20 \\
\hline $\begin{array}{l}\text { twenty-feet containers with on-ground } \\
\text { packing and jack loading }\end{array}$ & pcs & 16 & 12 & 13 & 16 \\
\hline $\begin{array}{l}\text { forty-feet containers with on-ground } \\
\text { packing and jack loading }\end{array}$ & pcs & 4 & 3 & 6 & 4 \\
\hline $\begin{array}{l}\text { Total number of containers shipped } \\
\text { with on-ground packing and jack } \\
\text { loading }\end{array}$ & pes & 20 & 15 & 19 & 20 \\
\hline $\begin{array}{l}\text { twenty-feet containers with truck } \\
\text { packaging }\end{array}$ & pcs & 5 & 18 & 11 & 5 \\
\hline $\begin{array}{l}\text { forty-feet containers with truck } \\
\text { packaging }\end{array}$ & pes & 19 & 16 & 16 & 19 \\
\hline $\begin{array}{l}\text { Total number of containers with truck } \\
\text { packaging }\end{array}$ & pes & 24 & 34 & 27 & 24 \\
\hline $\begin{array}{l}\text { Total number of twenty-feet container } \\
\text { shipped }\end{array}$ & pcs & 41 & 41 & 41 & 41 \\
\hline $\begin{array}{l}\text { Total number of forty-feet containers } \\
\text { shipped }\end{array}$ & pcs & 23 & 23 & 23 & 23 \\
\hline $\begin{array}{l}\text { Number of container packaging ways } \\
\text { used }\end{array}$ & pcs & 7 & 8 & 8 & 7 \\
\hline Total costs & Thousand rubles & 438.8 & 436.4 & 433.3 & 432.6 \\
\hline $\begin{array}{l}\text { Increase }(+) / \text { Reduction }(-) \text { of total } \\
\text { costs comparing with Scenario } 1\end{array}$ & $\%$ & - & $-0.55 \%$ & $-1.27 \%$ & $-1.43 \%$ \\
\hline
\end{tabular}

\section{Discussion}

The analysis according to Scenario 1 (basic) shows that, firstly, it will be required 64 containers to dispatch 1500 ton of container cargoes within a month -41 pcs of twenty-feet containers and 23 pcs of forty-feet ones, among others. Secondly, the optimal decision implies the use 7 of 12 possible ways of container shipment. Only two ways of shipment of twenty-feet containers (by trucks belonging to some third party with ground container packing and its further loading onto the truck with the use of jacks or container packaging without its unloading from the truck) and three ways of shipment of forty-feet containers 
(by owner's trucks with ground container packing and its further loading onto the truck with the use of the crane and jacks as well as by third-party trucks container packaging with ground container packing and its further loading onto the truck with the use of the crane). In this case, total cost of container shipment during four-week period is to be 438.8 thousand rubles.

Thirdly, the analysis of use of containers of different types (see Table 3) shows that the following ways of loading are used:

- on-ground loading with the use of the crane - twenty containers, including 19 twentyfeet ones and no forty-feet ones.

- on-ground loading with the use of jacks - 20 containers, including 16 twenty-feet ones and 4 forty-feet ones.

- loading onto the truck - 24 containers, including 5 twenty-feet ones and 19 twentyfeet ones.

Fourthly, conspicuous is the fact that the total number of warehoused twenty-feet containers is 10 pcs while the number of forty-feet ones is 4 pcs which is far less than the storage capacity which is limited by 20 pcs for twenty-feet containers and 10 pcs for fortyfeet ones. It is obvious that this number of warehoused containers is enough to amend the unevenness of their shipment to consumers from railroad goods depot.

The analysis of scenarios No. $2-4$, referring to the situation when the shipment of containers from the depot is delayed shows that, firstly, in all the cases, it will be required 64 container monthly to ship 1500 tons of containered goods, including 41 twenty-feet one and 23 forty-feet ones; but, each scenario assumes its own ways of container loading. Secondly, costs are reduced comparing with the basic variant: according to Scenario 2, the amount of reduction is $0.55 \%$, according to Scenario 3 it is to be $1.27 \%$ and, according to Scenario 4 , it is to be $1.43 \%$. The reduction of costs is due to easing of limitations in this task. First of all, the limitation of the amount of goods to be shipped from the depot within a week is a subject of such easing. It is obvious that due to shipment delay within a week the initial limitation $(\mathrm{Qt}=375 \mathrm{~T}, \mathrm{t}=\{1,2,3,4\})$ can't be honored. The number of containers shipped within a week, loaded from the ground or with the use of the crane is also the subject of limitation easing as well as the number of containers shipped within a week, loaded from the ground or with the use of jacks. One should note that this task has no solution, if the easing of this limitation is not implied.

\section{Conclusion}

The researching results prove that in case of breakouts (delays of container shipment from the railroad goods depot for one week) the reserve of loading capacity will be insufficient. Possible ways of solving this problem are the use of extra work or purchasing some additional equipment (a crane, jacks) for loading containers onto container chassis.

The analyzed example which is rather complicated one and based on real data shows that the analysis of costs does not always enable to make the right decision on ways of container shipment. Models of line programming which are powerful supporting tools in adopting managerial decisions should be used more actively by the managers. Here, we offer the dynamic multi-period task model of shipment of loaded containers allowing choosing optimal shipment strategy with allowances made for sufficient loading unevenness and breakouts of shipment from the railroad goods deport. The numerical solution is represented which confirms that the meth-od of dynamic linear programming can be successfully used to solve the problem of choice of the optimal shipment strategy under the conditions of sufficient unevenness of their loading and shipment. 


\section{References}

1. A.A. Bochkarev, P.A. Bochkarev, R.A. Franyuk, Audit and Financial Analysis. 5, 6173 (2018)

2. V. Gupta, , I. E. Grossmann, Computers \& Chemical Engineering, 35(11), 2235-2247 (2011).

3. A. B. Philpott, V. L. De Matos, European Journal of operational research, 218(2), 470483 (2012).

4. W.B. Powell, Naval Research Logistics 56(3), 239-249 (2009). DOI: 10.1002/nav.20347.

5. R.T. Rockafellar, Annals of Operations Research 85, 1-19 (1999). DOI: 10.1023/A:1018909508556.

6. M. Saint-Guillain, Y. Deville, C.Solnon, International Conference on AI and OR Techniques in Constriant Programming for Combinatorial Optimization Problems CPAIOR, 357-374. DOI: 10.1007/978-3-319-18008-3_25 (2015).

7. R. Schwartz, M. Housh, A. Ostfeld, Journal of Water Resources Planning and Management 142, 10 (2016). DOI: 10.1061/\%28ASCE\%29WR.1943-5452.0000687

8. S. Sen, Z. Zhou, SIAM Journal on Optimization 24(1), 127-153. DOI: $10.1137 / 120864854$ (2014).

9. S.A. Snyder, R.G. Haight, C.S. ReVelle, Environmental Modeling \& Assessment 9(3), 179-187 (2004). DOI: 10.1023/B:ENMO.0000049388.71603.7f.

10. A. Shapiro, Mathematical Methods of Operations Research 58(1), 57-68 (2003). DOI: 10.1007/s001860300280.

11. M.Q. Suo, Y.P. Li, G.H. Huang, Y.R. Fan, Z. Li, Mathematical Problems in Engineering 15, 482095, (2013). DOI: 10.1155/2013/482095.

12. Z. Zeng, S. Cremaschi, Processes 5(4) (2017). DOI: 10.3390/pr5040071.

13. N. Solonina, L. Alekseeva, S. Barykin, MATEC Web of Conferences 265, 07021 (2019). https://doi.org/10.1051/matecconf/201926507021

14. E. Schislyaeva, O. Saychenko, S. Barykin, I. Kapustina, International Scientific Conference Energy Management of Municipal Facilities and Sustainable Energy Technologies EMMFT 2018. EMMFT-2018 2018. Advances in Intelligent Systems and Computing, 983 (2019). https://doi.org/10.1007/978-3-030-19868-8_32

15. O. Kalinina, S. Firova, S. Barykin, I. Kapustina, International Scientific Conference Energy Management of Municipal Facilities and Sustainable Energy Technologies EMMFT 2018. EMMFT-2018 2018. Advances in Intelligent Systems and Computing, 982 (2020). https://doi.org/10.1007/978-3-030-19756-8_29 